\title{
Translation, cultural adaptation, and validation and reliability of assessment of pelvic floor disorders and their risk factors during pregnancy and postpartum questionnaire in Turkish population
}

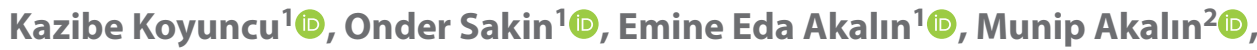 \\ Ali Doğukan Anğın' ${ }^{1}$, Yasmin Aboalhasan ${ }^{1}$ (D), Emel Sönmezer ${ }^{3}$ (i) \\ ${ }^{1}$ Department of Obstetrics and Gynecology, Health Sciences University, Dr. Lutfi KIrdar Kartal Training and Research Hospital, \\ Kartal, Istanbul, Turkey \\ ${ }^{2}$ Department of Obstetrics and Gynecology, Health Sciences University Zeynep Kamil Women and Children's Diseases Training \\ and Research Hospital, Istanbul, Turkey \\ ${ }^{3}$ Department of Physiotherapy, Başkent University Faculty of Medicine, Istanbul, Turkey
}

\begin{abstract}
Objectives: This study was conducted in order to produce translation, cultural adaptation, and validation of Assessment of Pelvic Floor Disorders and Their Risk Factors During Pregnancy and Postpartum Questionnaire (APFDQ) to Turkish in pregnant and postpartum population.

Material and methods: The study included 80 pregnant women. Internal consistency was tested using Cronbach's alpha. Questionnaires were applied three different times in order to assess for sensitivity. Patients were asked to complete the questionnaire first in the third trimester, secondly in postpartum $6^{\text {th }}$ week and finally in postpartum $6^{\text {th }}$ month after birth. For translation process content, face/content validity, reliability, construct validity and reactivity studies were done. All women had undergone pelvic examination and prolapse was assessed by using Pelvic organ Prolapse Quantification System (POP-Q). Urinary symptoms were also evaluated with Urinary Distress Inventory (UDI-6) questionnaire.

Results: The mean age of patients was $27.7 \pm 5.5$ years. Forty-one $(51.25 \%)$ of the patients had vaginal delivery and $39(48.75 \%)$ had a cesarean section. Above $96 \%$ of the patients had completed the questionnaires. POP-Q assessments and UDI- 6 results were used to evaluate construct validity. Cronbach's alpha results were found to be 0.7 for all the subscales of the questionnaire: bladder: 0.702 , bowel: 0.744 , prolapse: 0.701 , sexual function: 0.706 respectively, indicating adequate reliability. The test/retest reliability was studied and Pabak values showed moderate reliability in the bowel, prolapse and sexuality, and good reliability for bladder subscale. The results of the patients were compared between pregnancy and postpartum to assess reactivity and shown to be reactive to changes. Also risk factors of the patients were assessed including, family predisposition, maternal age over 35 years, $\mathrm{BMI}>25$, nicotine use, subjective inability to contract pelvic floor and sense of postpartum wound pain.
\end{abstract}

Conclusions: The Turkish version of APFDQ is a reliable and valid tool. It can be used for assessing the risk factors, incidence, assessing degree of PFDs and evaluating the impact on quality of life in pregnant and postpartum women.

Key words: pelvic floor dysfunction; pregnancy; postpartum; validation

Ginekologia Polska 2020; 91, 7: 394-405

\section{INTRODUCTION}

Pelvic floor dysfunction (PFDs) is a complex of urinary incontinence (UI), fecal incontinence (FI), pelvic organ prolapse (POP), sexual dysfunction, and other urogenital symptoms [1]. PFDs incidence was shown to be as high $67.5 \%$ of the women excluding pregnancy and postpartum period [2]. The prevalence of each pelvic floor was evaluated, and anal incontinence was found $19.8 \%$; urinary incontinence, $50.7 \%$; constipation, 33.2\%; and obstructed defecation, $26.8 \%[3,4]$. Childbirth is shown to be related to PFDs. Parity was 
found to be correlated with urinary incontinence in $50 \%$ of the patients and with prolapse in $75 \%$ of the cases [5]. Postpartum assessment of pelvic floor in terms of PFDs could lead to early diagnosis and intervention, and we could provide a protective health care [6].

PFDs are linked to physical and emotional stress, causing psychological problems and decreased quality of life [7]. But most of the patients discuss these problems with healthcare providers. Although pregnancy and postpartum periods are accepted as high-risk factors for pelvic floor trauma, it has not been studied thoroughly [8]. Further studies are needed to understand the effect of pregnancy and delivery on the pelvic floor structure.

In our opinion, questionnaires are fundamental for detecting the adverse effect of the disease to quality of life. In Turkey there are no validated questionnaires to address PFDs in pregnant and postpartum women. We aim to translate, validate and culturally adapt a APFDQ which detects PFDs regarding bladder function, bowel function, prolapse and sexual function with risk factors in pregnant and postpartum patients. Postpartum depression is also questioned to clarify the etiology of the decreased quality of life.

This questionnaire was constituted on previously validated German pelvic floor questionnaires in urogynecology patients [9]. New sections were added regarding risk factors, childbirth and impact on quality of life. Some of the questions were removed in order to adapt the questionnaire to younger patients (Annex 1 and 2).

\section{MATERIAL AND METHODS}

The original version of APFDQ was adapted to Turkish in the study.

Validation permission for the questionnaire was taken from the developer, Dr. Kaven Baessler for the use. Ethical board approval was taken from Zeynep Kamil Research and Training Hospital (19.12.2018/164).

\section{Translation and cultural adaptation}

The following guidelines were followed in order to validate the original version of APFDQ into Turkish [9].

Firstly, forward- backward translations were made for cross-cultural adaptations. The original German version APFDQ was translated to Turkish by a native speaker, then a professional translator performed a backward translation, followed by an expert committee including the researchers evaluated the version of the APFDQ. This version was applied, then volunteers in order to detect if there is any misunderstanding. Finally, the Turkish version of theAPFDQ was edited according to suggestions and used in patients.

\section{Questionnaire}

The APFDQ was based on the validated Australian Pelvic Floor Questionnaire which has four domains including bladder, bowel, support and sexual function [10-13]. There are completely newly developed sections in the APFDQ for risk factors and the course of childbirth. Participants fulfilled the childbirth domain at postpartum $6^{\text {th }}$ week, which elucidate the route of delivery, emotional effect of birth and postpartum pain for patient.

\section{Validity}

Ten volunteers had completed the questionnaire and were interviewed by the researchers to find out if there were any misinterpretations. The version was also discussed in the study group and counseled to the experts on this topic.

\section{Reliability}

Internal consistency and test- retest analysis are used to establish reliability. For an adequate internal consistency, Cronbach's Alpha value should be more 0.7 and more.

The questionnaire was given to patients in weekly intervals during the third trimester, to constitute test- retest reliability. The interval was shorter than the usual period for reliability regarding the concern for maintaining the same conditions in pregnant patients. PABAK value was used to establish the degree of agreement and intraclass correlation coefficient (ICC) to demonstrate the agreement of the test- retest results of the individuals.

\section{Reactivity "sensitivity to change"}

The questionnaire was giving weekly two different times first during the third trimester, then again during postpartum at $6^{\text {th }}$ week and $6^{\text {th }}$ month.

\section{Study population and data collection}

The questionnaire was giving to 92 women attending routine visits in two tertiary clinics in Istanbul. Inclusion criterias were age between 18-40 years and having uncomplicated pregnancy. Exclusion criterias were inadequate Turkish language knowledge, having chronic diseases, neurological disorders, preeclampsia, gestational diabetes mellitus, or fetal abnormalities.

Sample size was calculated taking into account the previous studies, with a power of $80 \%$ and $a=0.05$ a score change of 1 in a domain (minimal important clinical difference) can be significantly detected from a sample size of $n=50$ [12].

\section{Analysis of data}

The final version was validated according to COSMIN (The Consensus- based Standards for the selection of health Measurement Instruments) International guidelines [13]. 


\section{Statistical Analysis}

Numeric variables were expressed as the mean and standard deviation or as the median (minimum-maximum), depending on the distribution of the data. The normality was determined using the Shapiro-Wilk test. Internal consistency of the scale was assessed with Cronbach's alpha coefficient. Intra class correlation coefficient and Kappa along with PABAK (Prevalence adjusted Bias adjusted Kappa) were used for test-retest reliability. Hence some of the tables included sparse data, i.e. concordant cell frequencies were high and discordant frequencies were low, PABAK along with Kappa was reported. Effect sizes of the $6^{\text {th }}$ week to after delivery and the $3^{\text {rd }}$ trimester to after delivery was calculated by dividing the difference between the mean of measurements before and after delivery by the standard deviation of measurement before delivery $(\Delta / S D)$ for assessing the responsiveness of the scale. Comparisons of before and after delivery scores were also performed with Wilcoxon signed rank test.

Concurrent and construct validity was assessed with spearman correlation coefficient.

Interpretations of Kappa and PABAK values were performed according to the classification for the strength of agreement, which considers $\mathrm{K}$ values of $1-0.81$ to be almost

Table 1. Sociodemographic characteristics of the population

\begin{tabular}{|l|c|}
\hline Age & Mean \pm SD \\
\hline BMI & $27.7 \pm 5.5$ \\
\hline Income status & $28.6 \pm 4.8$ \\
\hline Low-income & $26(32.9 \%)$ \\
\hline Middle-income & $40(50.6 \%)$ \\
\hline High-income & $13(16.5 \%)$ \\
\hline Chronic disease & \\
\hline Yes & $69(87.3 \%)$ \\
\hline No & $10(12.7 \%)$ \\
\hline Previous abdominal surgery & \\
\hline Yes & $55(69.6 \%)$ \\
\hline No & $24(30.4 \%)$ \\
\hline
\end{tabular}

Mean \pm standard deviation was given for quantitative variables, whereas $n(\%)$ were given for qualitative ones in perfect agreement, $0.80-0.61$ to be in substantial agreement, $0.60-0.41$ to be in moderate agreement, $0.40-0.21$ to be in fair agreement, and $<0.20$ to be in slight agreement. $\mathrm{p}<0.05$ was considered statistically significant.

\section{RESULTS}

A total of 92 women in the of third trimester pregnancy were included the study. Twelve were excluded due to failure to follow-up. The remaining 80 patients were interviewed during the third trimester, postpartum $6^{\text {th }}$ week and postpartum $6^{\text {th }}$ month. Forty-one (51.25\%) patients had vaginal delivery and $39(48.75 \%)$ patients had a cesarean section. Figure 1 shows the study course. Thirty-five ( $43.75 \%$ ) women were primiparous and $56.25 \%$ were multiparous. The mean age of the women was $27.7 \pm 5.5$ years. The mean parity was $1.1 \pm 1.1$. The mean body mass index was $26.32 \pm 3.14$ of the patient group. Socio-demographic characteristics of the patients were summarized in Table 1. Mean gravida of the patients was $2.3 \pm 1.4$. Mean of the maximum weight of the babies delivered was $2332.3 \pm 1626.1$ grams. None of the patients had operative delivery. Obstetrics characteristics of the patients were summarized in Table 2. Prevalence for PFDs of the study population was shown in Table 3.

\section{Internal consistency reliability}

Cronbach's alpha value of domains were calculated and found to be over 0.7 points which is enough to show reliability of the questionnaire.

\section{Test-retest reliability}

PABAKvalues and ICC values were used to assess test-retest reliability and shown in Table 4. Therefore, while bladder

\section{Table 2. Obstetric characteristics of the study population}

\begin{tabular}{|l|c|}
\hline Gravida $($ mean \pm SD $)$ & $2.3 \pm 1.4$ \\
\hline Parity (mean \pm SD ) & $1.1 \pm 1.1$ \\
\hline Number of vaginal delivery $(n, \%)$ & $41(51.25 \%)$ \\
\hline Number of cesarean delivery $(n, \%)$ & $39(48.75)$ \\
\hline Episiotomy $(n, \%)$ & $11(22.91 \%)$ \\
\hline Mean birth wieght (mean \pm SD) & $2332.3 \pm 1626.1$ \\
\hline
\end{tabular}

Mean \pm standard deviation was given for quantitative variables, whereas $n(\%)$ were given for qualitative ones

Table 3. Prevalence of the PFDs in study population

\begin{tabular}{|c|c|c|c|}
\hline & Third trimester & Postpartum $6^{\text {th }}$ week & Postpartum $6^{\text {th }}$ month \\
\hline Urinary incontinence $\mathrm{n}(\%)$ & 78 (98.73\%) & $72(90 \%)$ & $64(80 \%)$ \\
\hline Anal incontinence $\mathrm{n}(\%)$ & $23(28.75 \%)$ & $18(22.5 \%)$ & $14(17.5 \%)$ \\
\hline Genital prolapse n (\%) & $26(32.5 \%)$ & $34(42.5 \%)$ & $31(38.75 \%)$ \\
\hline Sexual symptoms n (\%) & 45 (56.25\%) & 62 (77.5\%) & $32(40 \%)$ \\
\hline
\end{tabular}




\begin{tabular}{|l|c|c|c|}
\hline Table 4. Test-retest reliability & \multicolumn{1}{|c|}{ ICC } \\
\hline Bladder & Cronbach's alpha & 0.863 & 1.00 \\
\hline Bowel & 0.702 & 0.714 & 0.90 \\
\hline Prolapse & 0.744 & 0.735 & 0.54 \\
\hline Sexuality & 0.701 & 0.626 & 0.67 \\
\hline
\end{tabular}

\begin{tabular}{|l|c|c|c|c|c|c|c|}
\hline \multicolumn{1}{l|}{ Table 5. Reactivity } \\
\hline Bladder & $\mathbf{3}^{\text {rd }}$ trimester & $\mathbf{6}^{\text {th }}$ week & $\mathbf{6}^{\text {th }}$ month & ES1 & p & ES2 & p \\
\hline Bowel & $1.88(0-5)$ & $1.88(0-4.58)$ & $0.42(0-3.75)$ & 1.46 & $<0.001$ & 1.57 & $<0.001$ \\
\hline Prolapse & $1.29(0-5.16)$ & $0.97(0-4.52)$ & $0.97(0-2.26)$ & 0.5 & $<0.001$ & 0.41 & 0.003 \\
\hline Sexuality & $0(0-2.5)$ & $0.6(0-2.5)$ & $1.25(0-2.92)$ & -1.25 & $<0.001$ & -2.03 & $<0.001$ \\
\hline
\end{tabular}

Medians (range) were given; ES - Cohen's effect size was calculated by dividing the difference between the mean of measurements before and after delivery by the standard deviation of measurement before delivery $(\Delta / \mathrm{SD})$; ES1 - effect size of the third trimester to the $6^{\text {th }}$ week after delivery; ES2 - effect size of after the 6 th week to after the $6^{\text {th }}$ month delivery; comparison between the third trimester and postpartum, $\mathrm{p}$ values are based on Wilcoxon signed-rank test

and bowel showed acceptable internal consistency along with good test-retest reliability; prolapse and sexuality had acceptable internal consistency along with good and moderate test-retest reliability, respectively.

\section{Content validity}

The rate of missing answers did not exceed $4 \%$ for any of the questions in the final questionnaire.

\section{Construct validity}

Patients' bladder scores of the questionnaire was found to be significantly correlated to UDI-6 (rho: 0.806, p: 0.000), also prolapse scores were correlated to POP-Q scores significantly (rho: $0.574, \mathrm{p}: 0.000$ ).

\section{Reactivity and scoring system}

Mean scores of the domains were statistically different between pregnant and postpartum patients indicating the questionnaire is reactive to the changes $(p<0.01)$ (Tab. 5).

\section{DISCUSSION}

Here in this study we found showing that the Turkish version of the APFDQ is a reliable tool for evaluating pelvic floor disorders in pregnancy and postpartum period. Also it is a reliable questionnaire that we could follow the changes in different situations. The study population had a higher ratio of patients with chronic diseases (87.3\%). This might be explained by conducting the study in a tertiary center.

Pelvic floor dysfunction after birth is usually accepted as a "normal" situation that patients do not discuss with their healthcare professionals. So, it is underestimated and not well evaluated unless adressing the symptoms [14].
Questionnaires are accepted as a part of standard evaluation methods for pelvic floor disorders [15]. Pregnancy and delivery are well known factors for PFDs [16]. Yet there are not comprehensive questionnaires in the literature for pregnant and postpartum patients.

In the literature there are questionnaires which evaluates PFDs such as Pelvic Floor Disorders Inventory-20 (PFDI20), Pelvic Floor Distress Inventory (PFIQ-7), Pelvic Floor Disorders Inventory-46 (PFDI-46), Pelvic Floor Distress Inventory (PFIQ-31), International Consultation on Incontinence- Vaginal Symptoms (ICIQ-VS), Australian Pelvic Floor Questionnaire (or Australian PFQ), Pelvic Floor Bother Questionnaire (PFBQ), electronic Personal Assessment Questionnaire ePAQ-PF, and Pelvic Floor Dysfunction (PFD) [17-19].

PFDI-46 and PFIQ-31 are very time consuming, so new shorter versions were established as PFDI-20 and PFIQ-7. However, the new versions do not cover all the aspects of the PFDs and quality of life [20-21]. ICIQ-VS does not contain bladder and bowel functions [22]. From the above mentioned questionnaires, ePAQ, FPFQ and PFBQ are the only ones that evaluate all these areas but there are not widely used in the literature [23, 24]. ePAQ is not commonly used because of a license obligation. PFBQ is only translated to four languages so far and questions were not well distributed. FPFQ seems to address all the areas as it is newly developed, and it has not been widely translated to other languages [25-26].

None of the questionnaires above except APFDQ were originally developed to postpartum patients. APFDQ is also designed to evaluate specific risk factors for PFDs in postpartum period. 
It is important to detect these symptoms in the early period to prevent future advanced PFDs, and make an appropriate intervention. In this study we aimed to translate this questionnaire in order to detect PFDs in our population and reduce the adverse effect of PFDs to quality of life. Administering pelvic muscle training in the postpartum period (PFMT) is proven to improve pelvic floor function and quality of life (QOL) of the patients [27]. Although there are conflicting data in the literature, a recent randomised study showed that a two-tiered, self-selection approach had increased the pelvic floor function and QOL in women with or without incontinence. The two- tiered approach consists of an informative session about anatomy and physiology and then practical data about exercise was taught and a PFMT was constituted for home [27]. Cochrane review published in 2014 also suggests that PFMT could prevent incontinence for 6 months in continent women during pregnancy [28]. Also, women with urinary incontinence were found to benefit from PFMT up to 1 year after delivery [28]. Cochrane review published in 2017 suggested that if offered to continent women in early pregnancy, PFMT programme could reduce urinary incontinence in late pregnancy and postpartum period [29].

\section{CONSLUSIONS}

Linguistic validation is an important step in the validation process. In order to have a better understanding, translations were done by native speakers then it was controlled by the expert committee. At first, 10 volunteers were involved to the study and interviewed face to face in order to modify misunderstandings.

According to the results of this study, the Turkish version of APFDQ was a valid and reliable tool to assess pelvic floor disorders in the period of pregnancy and postpartum. The Turkish version of APFDQ could be used to evaluate the immediate status of the patients during pregnancy and postpartum or could be used to follow the changes according to the score changes. Discriminant validity showed a significant difference between the pregnancy and postpartum periods in all the subscales of the questionnaire. The Turkish version of APFDQ has high internal consistency, is reproducible and high construct validity, and can detect the degree of pelvic floor dysfunction. It has a high correlation with UDI 6 and moderate correlation with POP-Q.

The Turkish version of the self-administered APFDQ seems to be a reliable and valid instrument for evaluating PFDs symptoms severity and quality of life in Turkish speaking women.

\section{Disclosure}

All the authors state no financial disclosures or conflict of interest related to the content of this work.

\section{REFERENCES}

1. Haylen B, Maher C, Barber M, et al. An International Urogynecologica Association (IUGA)/International Continence Society (ICS) joint report on the terminology for female pelvic organ prolapse (POP). Int Urogynecol J. 2016; 27(2): 165-194, doi: 10.1007/s00192-015-2932-1.

2. Hallock JL, Handa VL. The Epidemiology of Pelvic Floor Disorders and Childbirth: An Update. Obstet Gynecol Clin North Am. 2016; 43(1): 1-13, doi: 10.1016/j.ogc.2015.10.008, indexed in Pubmed: 26880504.

3. Swift SE. The distribution of pelvic organ support in a population of female subjects seen for routine gynecologic health care. Am J Obstet Gynecol. 2000; 183(2): 277-285, doi: 10.1067/mob.2000.107583, indexed in Pubmed: 10942459.

4. Hendrix SL, Clark A, Nygaard I, et al. Pelvic organ prolapse in the Women's Health Initiative: gravity and gravidity. Am J Obstet Gynecol. 2002; 186(6): 1160-1166, doi: 10.1067/mob.2002.123819, indexed in Pubmed: 12066091

5. Iglesia CB, Smithling KR. Pelvic Organ Prolapse. Am Fam Physician. 2017; 96(3): 179-185, indexed in Pubmed: 28762694.

6. Woodley SJ, Lawrenson P, Boyle R, et al. Pelvic floor muscle training for prevention and treatment of urinary and faecal incontinence in antenatal and postnatal women. Cochrane Database Syst Rev. 2012; 10(3): CD007471-276, doi: 10.1002/14651858.CD007471.pub2, indexed in Pubmed: 23076935.

7. Tennstedt SL, Fitzgerald MP, Nager CW, et al. Urinary Incontinence Treatment Network. Quality of life in women with stress urinary incontinence. Int Urogynecol J Pelvic Floor Dysfunct. 2007; 18(5): 543-549, doi: 10.1007/s00192-006-0188-5, indexed in Pubmed: 17036169.

8. Smith FJ, Holman CD, Moorin RE, et al. Lifetime risk of undergoing surgery for pelvic organ prolapse. Obstet Gynecol. 2010; 116(5): 1096-1100, doi: 10.1097/AOG.0b013e3181f73729, indexed in Pubmed: 20966694.

9. Beaton DE, Bombardier C, Guillemin F, et al. Guidelines for the process of cross-cultural adaptation of self-report measures. Spine (Phila Pa 1976). 2000; 25(24): 3186-3191, doi: 10.1097/00007632-200012150-00014, indexed in Pubmed: 11124735.

10. Baessler $\mathrm{K}$, Kempkensteffen $\mathrm{C}$. [Validation of a comprehensive pelvic floor questionnaire for the hospital, private practice and research]. Gynakol Geburtshilfliche Rundsch. 2009; 49(4): 299-307, doi: 10.1159/000301098, indexed in Pubmed: 20530945.

11. Baessler K, O'Neill SM, Maher CF, et al. Australian pelvic floor questionnaire: a validated interviewer-administered pelvic floor questionnaire for routine clinic and research. Int Urogynecol J Pelvic Floor Dysfunct. 2009; 20(2): 149-158, doi: 10.1007/s00192-008-0742-4, indexed in Pubmed: 18958382.

12. Metz $M$, Junginger $B$, Henrich $W$, et al. Development and Validation of a Questionnaire for the Assessment of Pelvic Floor Disorders and Their Risk Factors During Pregnancy and Post Partum. Geburtshilfe und Frauenheilkunde. 2017; 77(04): 358-365, doi: 10.1055/s-0043-102693.

13. Mokkink LB, Terwee CB, Patrick DL, et al. The COSMIN checklist for assessing the methodological quality of studies on measurement properties of health status measurement instruments: an international Delphi study. Qual Life Res. 2010; 19(4): 539-549, doi: 10.1007/s11136-010-9606-8, indexed in Pubmed: 20169472.

14. Zuchelo LS, Bezerra IP, Silva AM, et al. Questionnaires to evaluate pelvic floor dysfunction in the postpartum period: a systematic review. International Journal of Women's Health. 2018; Volume 10: 409-424, doi: 10.2147/ijwh.s164266.

15. Kaplan PB, Sut N, Sut HK. Validation, cultural adaptation and responsiveness of two pelvic-floor-specific quality-of-life questionnaires, PFDI-20 and PFIQ7, in a Turkish population. Eur J Obstet Gynecol Reprod Biol. 2012; 162(2): 229-233, doi: 10.1016/j.ejogrb.2012.03.004, indexed in Pubmed: 22480412.

16. Zuchelo LT, Bezerra IM, Da Silva AT, et al. Questionnaires to evaluate pelvic floor dysfunction in the postpartum period: a systematic review. Int J Womens Health. 2018; 10: 409-424, doi: 10.2147/IJWH.S164266, indexed in Pubmed: 30123009.

17. Hunskaar $S$, Lose $G$, Sykes $D$, et al. The prevalence of urinary incontinence in women in four European countries. BJU Int. 2004; 93(3): 324-330, doi: 10.1111/j.1464-410x.2003.04609.x, indexed in Pubmed: 14764130.

18. Barber MD, Walters MD, Bump RC. Short forms of two condition-specific quality-of-life questionnaires for women with pelvic floor disorders (PFDI-20 and PFIQ-7). Am J Obstet Gynecol. 2005; 193(1): 103-113, doi: 10.1016/j.ajog.2004.12.025, indexed in Pubmed: 16021067.

19. Price N, Jackson SR, Avery K, et al. Development and psychometric evaluation of the ICIQ Vaginal Symptoms Questionnaire: the ICIQ-VS. BJOG. 2006; 113(6): 700-712, doi: 10.1111/j.1471-0528.2006.00938.x, indexed in Pubmed: 16709214. 
20. Baessler $\mathrm{K}, \mathrm{O}^{\prime}$ Neill $\mathrm{SM}$, Maher $\mathrm{CF}$, et al. A validated self-administered female pelvic floor questionnaire. Int Urogynecol J. 2010; 21(2): 163-172, doi: 10.1007/s00192-009-0997-4, indexed in Pubmed: 19756341.

21. Barber MD, Kuchibhatla MN, Pieper CF, et al. Psychometric evaluation of 2 comprehensive condition-specific quality of life instruments for women with pelvic floor disorders. Am J Obstet Gynecol. 2001; 185(6): 13881395, doi: 10.1067/mob.2001.118659, indexed in Pubmed: 11744914.

22. Barber MD, Walters MD, Bump RC. Short forms of two condition-specific quality-of-life questionnaires for women with pelvic floor disorders (PFDI-20 and PFIQ-7). Am J Obstet Gynecol. 2005; 193(1): 103-113, doi: 10.1016/j.ajog.2004.12.025, indexed in Pubmed: 16021067.

23. Price N, Jackson SR, Avery K, et al. Development and psychometric evaluation of the ICIQ Vaginal Symptoms Questionnaire: the ICIQ-VS. BJOG. 2006; 113(6): 700-712, doi: 10.1111/j.1471-0528.2006.00938.x, indexed in Pubmed: 16709214.

24. Radley SC, Jones GL, Tanguy EA, et al. Computer interviewing in urogynaecology: concept, development and psychometric testing of an electronic pelvic floor assessment questionnaire in primary and secondary care. BJOG. 2006; 113(2): 231-238, doi: 10.1111/j.1471-0528 2005.00820.x, indexed in Pubmed: 16412003.
25. Peterson TV, Karp DR, Aguilar VC, et al. Validation of a global pelvic floor symptom bother questionnaire. Int Urogynecol J. 2010; 21(9): 1129-1135, doi: 10.1007/s00192-010-1148-7, indexed in Pubmed: 20458467.

26. da Silva AT, Menezes CL, de Sousa Santos EF, et al. Referral gynecological ambulatory clinic: principal diagnosis and distribution in health services. BMC Womens Health. 2018; 18(1): 8, doi: 10.1186/s12905-0170498-4, indexed in Pubmed: 29304796.

27. Gagnon LH, Boucher J, Robert M. Impact of pelvic floor muscle training in the postpartum period. Int Urogynecol J. 2016; 27(2): 255-260, doi: 10.1007/s00192-015-2822-6, indexed in Pubmed: 26282094.

28. Boyle R, Hay-Smith EJ, Cody JD, et al. Pelvic floor muscle training for prevention and treatment of urinary and fecal incontinence in antenatal and postnatal women: a short version Cochrane review. Neurourol Urodyn. 2014; 33(3): 269-276, doi: 10.1002/nau.22402, indexed in Pubmed: 23616292.

29. Woodley SJ, Boyle R, Cody JD, et al. Pelvic floor muscle training for prevention and treatment of urinary and faecal incontinence in antenatal and postnatal women. Cochrane Database Syst Rev. 2017; 12: CD007471, doi: 10.1002/14651858.CD007471.pub3, indexed in Pubmed: 29271473. 


\begin{tabular}{|c|c|c|c|c|c|}
\hline \multicolumn{5}{|c|}{ MODULE RISK FACTORS } & RISK \\
\hline Height $\bigcirc 0 \mathrm{~cm}$ & Weight $\bigcirc 0 \mathrm{~kg}$ & Weight before pregnancy For BMI & $\mathrm{kg}$ & BMI $\bigcirc$ & $>25$ \\
\hline \multicolumn{4}{|l|}{ Age } & years & $>35$ \\
\hline \multicolumn{3}{|c|}{$\begin{array}{l}\text { Are there any women in your family to whom you are related by blood who have urinary } \\
\text { incontinence, fecal incontinence, or prolapse of the pelvic organs? }\end{array}$} & no & don't know & yes \\
\hline \multicolumn{3}{|l|}{ Do you smoke? } & no & stopped & yes \\
\hline \multicolumn{3}{|c|}{ Can you voluntarily contract your pelvic floor? } & yes & don't know & no \\
\hline
\end{tabular}

\begin{tabular}{|c|c|c|c|c|}
\hline Bladder function & 0 & 1 & 2 & 3 \\
\hline $\begin{array}{l}\text { 1. How often do you urinate during the day? } \\
\text { Pollakiuria }\end{array}$ & Every 3 hours & Every 2 hours & Once every hour & More often \\
\hline $\begin{array}{l}\text { 2. How often do you wake up at night } \\
\text { because you need to urinate? } \\
\text { Nocturia }\end{array}$ & & $2 x$ & $3 x$ & More than $3 x$ \\
\hline $\begin{array}{l}\text { 3. Do you lose urine in your sleep? } \\
\text { Nocturnal enuresis }\end{array}$ & Never & $\begin{array}{c}\text { Sometimes } \\
\text { - less than once a week }\end{array}$ & $\begin{array}{c}\text { Often } \\
\text { - once a week or more }\end{array}$ & $\begin{array}{l}\text { Usually } \\
\text { - every day }\end{array}$ \\
\hline $\begin{array}{l}\text { 4. Is the urge to urinate so strong that you } \\
\text { must immediately rush to the toilet? } \\
\text { Strong urge to urinate }\end{array}$ & Never & $\begin{array}{l}\text { Sometimes } \\
\text { — less than once a week }\end{array}$ & $\begin{array}{c}\text { Often } \\
\text { — once a week or more }\end{array}$ & $\begin{aligned} & \text { Usually } \\
& \text { - every day }\end{aligned}$ \\
\hline $\begin{array}{l}\text { 5. When you have a sudden strong urge to } \\
\text { urinate, do you leak urine before you reach } \\
\text { the toilet? } \\
\text { Urge incontinence }\end{array}$ & Never & $\begin{array}{c}\text { Sometimes } \\
\text { — less than once a week }\end{array}$ & $\begin{array}{c}\text { Often } \\
\text { — once a week or more }\end{array}$ & $\begin{array}{l}\text { Usually } \\
\text { - every day }\end{array}$ \\
\hline $\begin{array}{l}\text { 6. Do you leak urine when coughing, } \\
\text { sneezing, laughing, lifting or during } \\
\text { sports? } \\
\text { Stress incontinence }\end{array}$ & Never & $\begin{array}{c}\text { Sometimes } \\
\text { — less than once a week }\end{array}$ & $\begin{array}{c}\text { Often } \\
\text { — once a week or more }\end{array}$ & $\begin{array}{l}\text { Usually } \\
\text { - every day }\end{array}$ \\
\hline $\begin{array}{l}\text { 7. Is your urinary stream weak, slow or } \\
\text { prolonged? } \\
\text { Urinary stream }\end{array}$ & Never & $\begin{array}{c}\text { Sometimes } \\
\text { — less than once a week }\end{array}$ & $\begin{array}{c}\text { Often } \\
\text { — once a week or more }\end{array}$ & $\begin{array}{c}\text { Usually } \\
\text { - every day }\end{array}$ \\
\hline $\begin{array}{l}\text { 8. Do you feel that you can accurately assess } \\
\text { how full your bladder is? } \\
\text { Bladder estimate }\end{array}$ & Yes - always & Usually & Sometimes & No - never \\
\hline $\begin{array}{l}\text { 9. Do you feel that you cannot completely } \\
\text { empty your bladder? } \\
\text { Residual urine }\end{array}$ & Never & $\begin{array}{l}\text { Sometimes } \\
\text { — less than once a week }\end{array}$ & $\begin{array}{c}\text { Often } \\
\text { — once a week or more }\end{array}$ & $\begin{array}{c}\text { Usually } \\
\text { - every day }\end{array}$ \\
\hline $\begin{array}{l}\text { 10. Do you need to squeeze to urinate? } \\
\text { Squeeze }\end{array}$ & Never & $\begin{array}{c}\text { Sometimes } \\
\text { — less than once a week }\end{array}$ & $\begin{array}{c}\text { Often } \\
\text { — once a week or more }\end{array}$ & $\begin{array}{l}\text { Usually } \\
\text { - every day }\end{array}$ \\
\hline $\begin{array}{l}\text { 11. Do you wear panty liners or sanitary pads } \\
\text { because of urine leakage? } \\
\text { Pads }\end{array}$ & Never & $\begin{array}{c}\text { Sometimes } \\
\text { — only as prophylaxis }\end{array}$ & $\begin{array}{c}\text { Often } \\
\text { - during sports/during colds }\end{array}$ & $\begin{aligned} & \text { Usually } \\
& \text { - every day }\end{aligned}$ \\
\hline $\begin{array}{l}\text { 12. Do you limit the amount you drink to avoid } \\
\text { leaking urine? } \\
\text { Drinking patterns }\end{array}$ & Never & $\begin{array}{c}\text { Sometimes } \\
\text { — less than once a week }\end{array}$ & $\begin{array}{c}\text { Often } \\
\text { — once a week or more }\end{array}$ & $\begin{aligned} & \text { Usually } \\
& \text { - every day }\end{aligned}$ \\
\hline $\begin{array}{l}\text { 13. Do you experience a burning or dragging } \\
\text { sensation or pain when you urinate? } \\
\text { Dysuria }\end{array}$ & Never & $\begin{array}{c}\text { Sometimes } \\
\text { — less than once a week }\end{array}$ & $\begin{array}{c}\text { Often } \\
\text { — once a week or more }\end{array}$ & $\begin{aligned} & \text { Usually } \\
& \text { - every day }\end{aligned}$ \\
\hline $\begin{array}{l}\text { 14. How often do you have urinary tract } \\
\text { infections? } \\
\text { UTI }\end{array}$ & Rarely or never & $1-3 x$ per year & $4-12 \times$ per year & $\begin{array}{l}1 \times \text { or } \\
\text { more } / \text { month }\end{array}$ \\
\hline
\end{tabular}

Annex 1. The new version of the questionnaire*; Pelvic Floor Questionnaire for pregnant and post partum women *This is a simple translation of the questionnaire. This version has not been validated in English 


\begin{tabular}{|c|c|c|c|c|c|}
\hline $\begin{array}{l}\text { 15. Does the involuntary } \\
\text { loss of urine adversely } \\
\text { affect your daily life? } \\
\text { (e.g. sports activities, job, } \\
\text { shopping, going out) } \\
\text { QoL }\end{array}$ & $\begin{array}{l}\text { Not applicable, } \\
\text { I do not have } \\
\text { symptoms }\end{array}$ & Not at all & A little & Quite a lot & Very much \\
\hline $\begin{array}{l}\text { 16. How much do your } \\
\text { bladder symptoms } \\
\text { bother you? } \\
\text { Psychological stress from } \\
\text { bladder symptoms }\end{array}$ & $\begin{array}{l}\text { Not applicable, } \\
\text { I do not have } \\
\text { symptoms }\end{array}$ & Not at all & A little & Quite a lot & Very much \\
\hline \multicolumn{2}{|l|}{ Bowel function } & 0 & 1 & 1 & 2 \\
\hline \multicolumn{2}{|c|}{$\begin{array}{l}\text { 1. How often do you have a bowel } \\
\text { movement? } \\
\text { Frequency }\end{array}$} & $\begin{array}{l}\text { Every } 3 \text { days to } \\
\text { once a day }\end{array}$ & More than $1 x$ per day & Every 3 days or less often & $\begin{array}{l}\text { less than once } \\
\text { a week }\end{array}$ \\
\hline \multicolumn{2}{|c|}{$\begin{array}{l}\text { 2. What is the normal consistency of your } \\
\text { stools? } \\
\text { Consistency }\end{array}$} & soft or shaped & varying consistency & very hard & thin/mushy \\
\hline \multicolumn{2}{|l|}{ Bowel function } & 0 & 1 & 2 & 3 \\
\hline \multicolumn{2}{|c|}{$\begin{array}{l}\text { 3. Do you need to strain to have a bowel } \\
\text { movement? } \\
\text { Straining }\end{array}$} & Never & $\begin{array}{c}\text { Sometimes - less than once } \\
\text { a week }\end{array}$ & $\begin{array}{c}\text { Often - once a week or } \\
\text { more }\end{array}$ & $\begin{array}{l}\text { Usually } \\
\text { - every day }\end{array}$ \\
\hline \multicolumn{2}{|c|}{$\begin{array}{l}\text { 4. Do you suffer from constipation? } \\
\text { Constipation }\end{array}$} & Never & $\begin{array}{c}\text { Sometimes - less than once } \\
\text { a week }\end{array}$ & $\begin{array}{l}\text { Often - once a week or } \\
\text { more }\end{array}$ & $\begin{array}{l}\text { Usually } \\
\text { - every day }\end{array}$ \\
\hline \multicolumn{2}{|c|}{$\begin{array}{l}\text { 5. Do you experience involuntary flatulence } \\
\text { which you cannot suppress? } \\
\text { Flatus incontinence }\end{array}$} & Never & $\begin{array}{c}\text { Sometimes - less than once } \\
\text { a week }\end{array}$ & $\begin{array}{l}\text { Often - once a week or } \\
\text { more }\end{array}$ & $\begin{array}{c}\text { Usually } \\
\text { - every day }\end{array}$ \\
\hline \multicolumn{2}{|c|}{$\begin{array}{l}\text { 6. Do you experience an urge to defecate } \\
\text { which you cannot suppress? } \\
\text { Urge bowel incontinence }\end{array}$} & Never & $\begin{array}{c}\text { Sometimes - less than once } \\
\text { a week }\end{array}$ & $\begin{array}{c}\text { Often - once a week or } \\
\text { more }\end{array}$ & $\begin{array}{c}\text { Usually } \\
\text { - every day }\end{array}$ \\
\hline \multicolumn{2}{|c|}{$\begin{array}{l}\text { 7. Do you find traces of fecal soiling on your } \\
\text { underwear or pads? } \\
\text { Stool smears }\end{array}$} & Never & $\begin{array}{c}\text { Sometimes - less than once } \\
\text { a week }\end{array}$ & $\begin{array}{c}\text { Often - once a week or } \\
\text { more }\end{array}$ & $\begin{array}{c}\text { Usually } \\
\text { - every day }\end{array}$ \\
\hline \multicolumn{2}{|c|}{$\begin{array}{l}\text { 8. Do you experience accidental bowel } \\
\text { leakage with loss of feces? } \\
\text { Fecal incontinence }\end{array}$} & Never & $\begin{array}{l}\text { Sometimes - less than once } \\
\text { a week }\end{array}$ & $\begin{array}{c}\text { Often - once a week or } \\
\text { more }\end{array}$ & $\begin{array}{c}\text { Usually } \\
\text { - every day }\end{array}$ \\
\hline \multicolumn{2}{|c|}{$\begin{array}{l}\text { 9. Do you have the feeling that you cannot } \\
\text { completely empty your bowels? } \\
\text { Bowel dysfunction }\end{array}$} & Never & $\begin{array}{c}\text { Sometimes - less than once } \\
\text { a week }\end{array}$ & $\begin{array}{l}\text { Often - once a week or } \\
\text { more }\end{array}$ & $\begin{array}{c}\text { Usually } \\
\text { - every day }\end{array}$ \\
\hline $\begin{array}{l}\text { 10. Do the symptoms } \\
\text { adversely affect your } \\
\text { daily life? (planning your } \\
\text { day, sports activities, job, } \\
\text { shopping, going out) } \\
\text { QoL }\end{array}$ & $\begin{array}{l}\text { Not applicable, } \\
\text { I do not have } \\
\text { symptoms }\end{array}$ & Not at all & A little & Quite a lot & Very much \\
\hline $\begin{array}{l}\text { 11. How much do your } \\
\text { bowel symptoms bother } \\
\text { you? } \\
\text { Psychological stress from } \\
\text { bowel symptoms }\end{array}$ & $\begin{array}{l}\text { Not applicable, } \\
\text { I do not have } \\
\text { symptoms }\end{array}$ & Not at all & A little & Quite a lot & Very much \\
\hline
\end{tabular}




\begin{tabular}{|c|c|c|c|c|c|}
\hline \multicolumn{2}{|l|}{ Prolapse } & 0 & 1 & 2 & 3 \\
\hline \multicolumn{2}{|c|}{$\begin{array}{l}\text { 1. Do you feel as though there is a foreign } \\
\text { body in your vagina? } \\
\text { Foreign body }\end{array}$} & Never & $\begin{array}{c}\text { Sometimes } \\
\text { — less than once a week }\end{array}$ & $\begin{array}{c}\text { Often } \\
\text { — once a week or more }\end{array}$ & $\begin{array}{l}\text { Usually } \\
\text { - every day }\end{array}$ \\
\hline \multicolumn{2}{|c|}{$\begin{array}{l}\text { 2. Do you feel that your vagina or uterus may } \\
\text { have dropped? } \\
\text { Prolapse feeling }\end{array}$} & Never & $\begin{array}{l}\text { Sometimes } \\
\text { - less than once a week }\end{array}$ & $\begin{array}{c}\text { Often } \\
\text { - once a week or more }\end{array}$ & $\begin{array}{l}\text { Usually } \\
\text { - every day }\end{array}$ \\
\hline \multicolumn{2}{|c|}{$\begin{array}{l}\text { 3. Do you have the feeling that your vagina or } \\
\text { uterus drops when you lift something, walk } \\
\text { or run? } \\
\text { Prolapse under stress }\end{array}$} & Not at all & A little & Quite a lot & Very much \\
\hline $\begin{array}{l}\text { 4. Do these symptoms } \\
\text { adversely affect your } \\
\text { daily life? (e.g. sports } \\
\text { activities, job, shopping, } \\
\text { going out) } \\
\text { QoL }\end{array}$ & $\begin{array}{c}\text { Not applicable, } \\
\text { Ido not have } \\
\text { symptoms }\end{array}$ & Not at all & A little & Quite a lot & Very much \\
\hline $\begin{array}{l}\text { 5. How much does prolapse } \\
\text { bother you? } \\
\text { Psychological stress from } \\
\text { prolapse }\end{array}$ & $\begin{array}{c}\text { Not applicable, } \\
\text { Ido not have } \\
\text { symptoms }\end{array}$ & Not at all & A little & Quite a lot & Very much \\
\hline
\end{tabular}

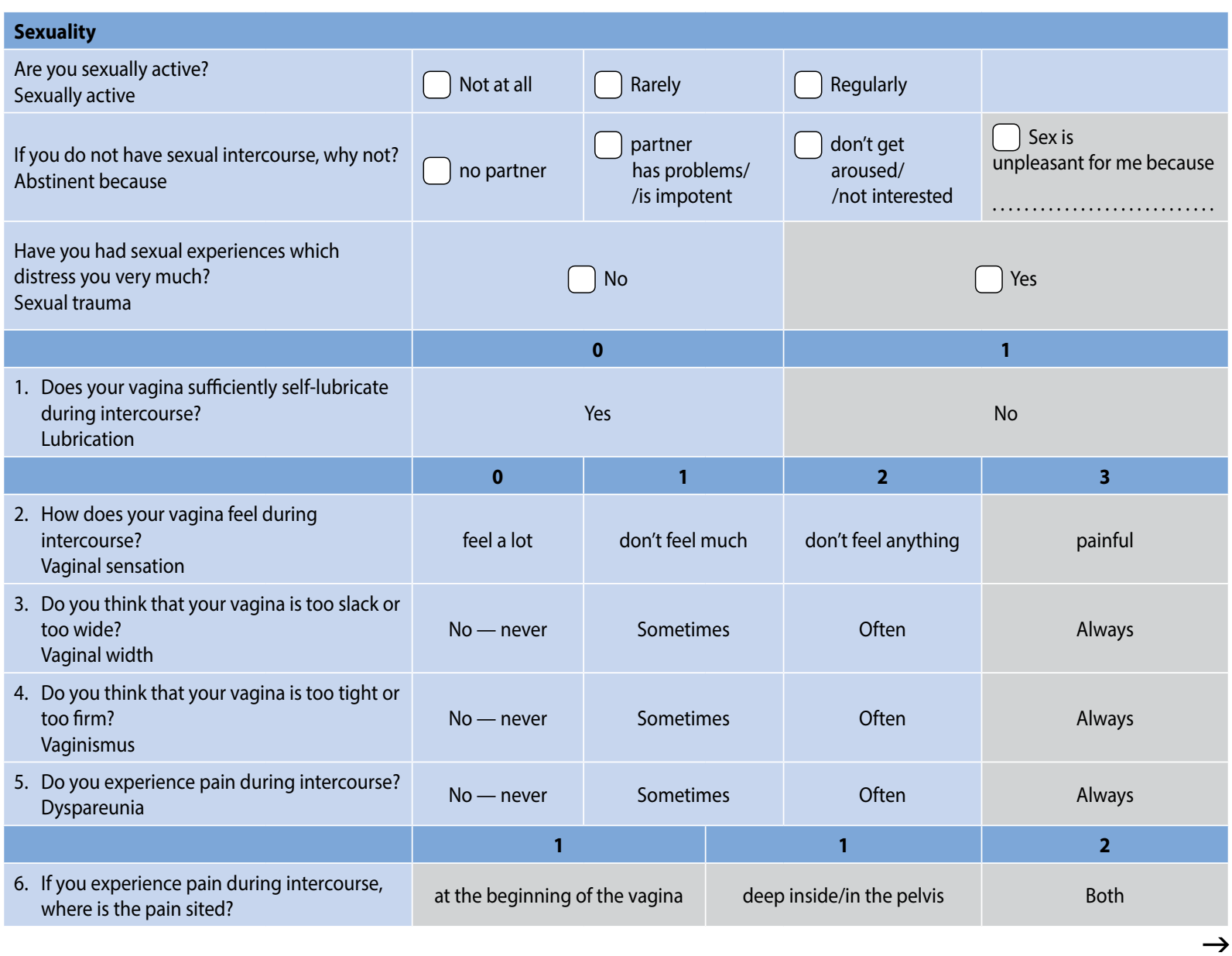




\begin{tabular}{|l|l|l|l|l|l|}
\hline $\begin{array}{l}\text { 7. Do you have involuntary loss of urine or } \\
\text { feces during sex? } \\
\text { Coital incontinence }\end{array}$ & No - never & Sometimes & Often & Always \\
\hline $\begin{array}{l}\text { 8. Do these symptoms } \\
\text { adversely affect your } \\
\text { sexuality? } \\
\text { QoL }\end{array}$ & $\begin{array}{c}\text { Not applicable, } \\
\text { Ido not have } \\
\text { symptoms }\end{array}$ & Not at all & A little & Quite a lot & Very much \\
\hline $\begin{array}{l}\text { 9. How much do these } \\
\text { symptoms bother you? } \\
\text { Psychological stress } \\
\text { because of sex }\end{array}$ & $\begin{array}{c}\text { Not applicable, } \\
\text { Ido not have } \\
\text { symptoms }\end{array}$ & Not at all & A little & Quite a lot & Very much \\
\hline
\end{tabular}

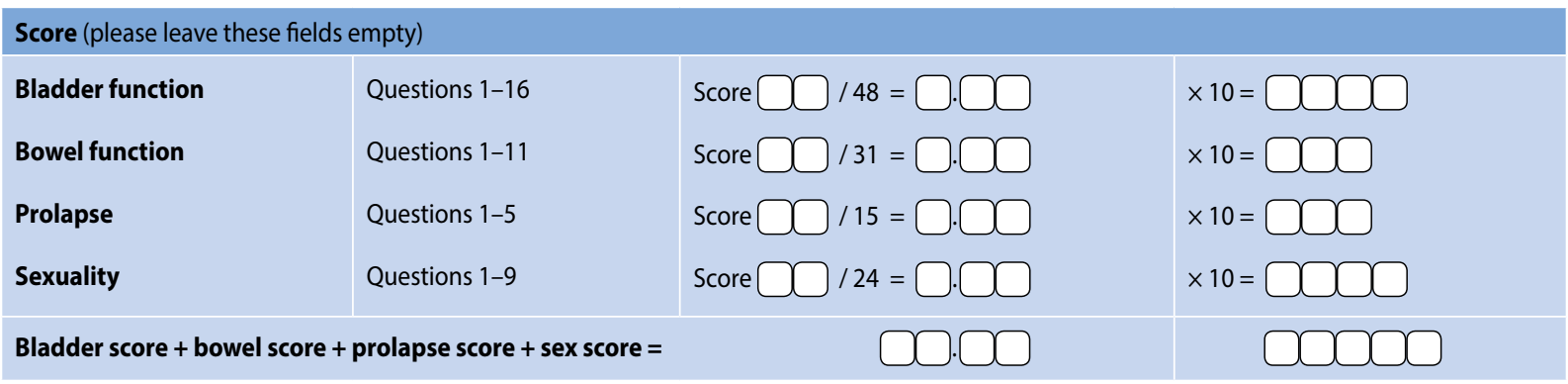

\begin{tabular}{|l|l|l|l|}
\hline Postpartum module & Risk \\
\hline How many children have you born? & $\begin{array}{l}\text { How many births were ventouse (vacuum, suction cup)- } \\
\text { assisted births? }\end{array}$ \\
\hline How many were born by cesarean section? & How many births were forceps-assisted births? \\
\hline $\begin{array}{l}\text { How heavy was your heaviest child at birth? } \\
\begin{array}{l}\text { Was the sphincter muscle, bowel or perineum injured } \\
\text { during any of your births (3rd or 4th degree perineal tear)? }\end{array}\end{array}$ \\
\hline $\begin{array}{l}\text { Did you have pain postpartum in the area of the vagina, } \\
\text { perineum or bowel/anus/rectum? }\end{array}$ & $\square$ No & \\
\hline $\begin{array}{l}\text { Do you feel that you have since been able to process the } \\
\text { birth pains or the pain experienced after the birth? }\end{array}$ & $\square$ Yes & $\square$ Largely & \\
\hline $\begin{array}{l}\text { Do you feel that you have since been able to process the } \\
\text { fears you had during the birth? }\end{array}$ & $\square$ Yes & $\square$ Largely & $\square$ A little \\
\hline
\end{tabular}




\section{AUSTRALIAN PELVIC FLOOR} QUESTIONNAIRE
Patient's Name:

Date of Birth:
Date completed:

Please circle your most applicable answer. Consider your experience during the last month.

\section{BLADDER FUNCTION ( $\ldots \ldots$ / 45)}

Q1. How many times do you pass urine in a day?
0 Up to 7
1 Between 8-10
2 Between 11-15
3 More than 15

Q4. Do you need to rush/hurry to pass urine when you get the urge?
0 Can hold on
1 Occasionally must rush - less than once/week
2 Frequently must rush - once or more/week
3 Daily
Q7. Is your urinary stream (urine flow) weak, prolonged or slow?
0 Never
1 Occasionally - less than once perweek
2 Frequently - once or more per week
3 Daily

\section{Q10. Do you have to wear pads because of} urinary leakage?
0 None - Never
1 As a precaution
2 When exercising/during a cold
3 Daily

Q13. Do you have pain in your bladder or urethra when you empty your bladder?
0 Never
1 Occasionally - less than once per week
2 Frequently - once or more per week
3 Daily

Q2. How many times do you get up at night to pass urine?
0 0-1
12
23
3 More than 3 times

Q5. Does urine leak when you rush or hurry tothetoiletorcan'tyoumakeitin time?

0 Not at all

1 Occasionally - less than once per week

2 Frequently - once or more per week

3 Daily

Q8. Do you have a feeling of incomplete bladder emptying?

0 Never

1 Occasionally - less than once per week

2 Frequently - once or more per week

3 Daily

Q11. Do you limit your fluid intake to decrease urinary leakage?
0 Never
1 Before going out
2 Moderately
3 Always

Q14. Does urine leakage affect your routine activities like recreation, socializing, sleeping, shopping etc?

0 Not at all

1 Slightly

2 Moderately

3 Greatly
Q3. Do you wet the bed before you wake up at night?

0 Never

1 Occasionally - less than once per week

2 Frequently - once or more per week

3 Always - every night

Q6. Do you leak with coughing, sneezing, laughing or exercising?

0 Not at all

1 Occasionally - less than once per week

2 Frequently - once or more per week

3 Daily

Q9. Do you need to strain to empty your bladder?

0 Neve

1 Occasionally - less than once per week

2 Frequently - once or more per week

3 Daily

\section{Q12. Do you have frequent bladder} infections?
0 No
1 1-3 per year
2 4-12 per year
3 More than one per month

\section{Q15. How much does your bladder problem} bother you?

0 Not at all

1 Slightly

2 Moderately

3 Greatly

Other symptoms (haematuria, pain etc.)

\section{BOWEL FUNCTION ( . ... /34)}

Q16. How often do you usually open your bowels?
0 Every other day or daily
1 Less than every 3 days
2 Less than once a week
0 More than once per day

\section{Q19. Do you use laxatives to empty your} bowels?
0 Never
1 Occasionally - less than once per week
2 Frequently - once or more per week
3 Daily

\section{Q17. How is the consistency of your usual} stool?
0 Soft
0 Firm
0 Hard (pebbles)
1 Variable
2 Watery
Q20. Do you feel constipated?
0 Never
1 Occasionally - less than once per week
2 Frequently - once or more per week
3 Daily

\section{Q18. Do you have to strain to empty your} bowels?
0 Never
1 Occasionally - less than once per week
2 Frequently - once or more per week
3 Daily

\section{Q21. When you get wind or flatus, can you control it, or does wind leak? \\ 0 Never \\ 1 Occasionally - less than once per week \\ 2 Frequently - once or more perweek \\ 3 Daily}

Annex 2. The old version of the questionnaire 


\section{AUSTRALIAN PELVIC FLOOR QUESTIONNAIRE}

Q22. Do you get an overwhelming sense of urgency to empty bowels?

0 Never

1 Occasionally - less than once per week

2 Frequently - once or more per week

3 Daily

Q25. Do you have a feeling of incomplete bowel emptying?

0 Never

1 Occasionally - less than once per week

2 Frequently - once or more per week

3 Daily

\section{PROLAPSE SYMPTOMS} /15)

Q28. Do you have a sensation of tissue protrusion/lump/bulging in your vagina?

0 Never

1 Occasionally - less than once per week

2 Frequently - once or more per week

3 Daily

\section{Q31. Do you have to push back your} prolapse to empty your bowels?

0 Never

1 Occasionally - less than once per week

2 Frequently - once or more per week

3 Daily

\section{SEXUAL FUNCTION} /21)

\section{Q33. Are you sexually active?}

$\square$ No
$\square$ Less than once per week
$\square$ Once or more per week
Daily or most days

If you are not sexually active, please continue to answer questions $34 \& 42$.

\section{Q36. During intercourse vaginal sensation is:}

0 Normal/pleasant

1 Minimal

2 Painful

3 None

\section{Q39. Do you experience pain with sexual} intercourse?
0 Never
1 Occasionally
2 Frequently
3 Always

\section{Q42. How much do these sexual issues} bother you?
$\square$ Not applicable
0 Not at all
1 Slightly
2 Moderately
3 Greatly

Patient's Name:

Date of Birth:

Date completed:

\section{Q23. Do you leak watery stool when you do not mean to? \\ 0 Never \\ 1 Occasionally - less than once per week \\ 2 Frequently - once or more per week \\ 3 Daily \\ Q24. Do you leak normal stool when you do not mean to? \\ 0 Never \\ 1 Occasionally - less than once per week \\ 2 Frequently - once or more per week \\ 3 Daily}

Q26. Do you use finger pressure to help empty your bowel?

0 Never

1 Occasionally - less than once per week

2 Frequently - once or more per week

3 Daily
Q27. How much does your bowel problem bother you?

1 Slightly

2 Moderately

3 Greatly
0 Not at all
Q29. Do you experience vaginal pressure or heaviness or a dragging sensation?

0 Never

1 Occasionally - less than once per week

2 Frequently - once or more per week

3 Daily

\section{Q32. How much does your prolapse bother} you?

0 Not at all

1 Slightly

2 Moderately

3 Greatly
Q30. Do you have to push back prolapse in order to void?

0 Never

1 Occasionally - less than once per week

2 Frequently - once or more per week

3 Daily

Other Symptoms: (problems: walking/sitting, pain, vaginal bleeding)
Q34. If you are not sexually active, please tell us why?

$\square$ Do not have a partner
I am not interested
My partner is unable
Vaginal dryness
Too painful
Embarrassment due to the prolapse/
Othcontinence
Other reasons:..........................

\section{Q37. Do you feel that your vagina is too}

\section{loose or lax?}

0 Never

1 Occasionally

2 Frequently

3 Always

\section{Q40. Where does the pain during} intercourse occur?

0 Not applicable, I do not have pain

1 At the entrance to the vagina

2 Deep inside, in the pelvis

3 Both at the entrance \& in the pelvis

\section{Q35. Do you have sufficient vaginal} lubrication during intercourse?

\section{$\square$ Yes \\ No}

Q43. Other symptoms? (faecal incontinence, vaginismus etc)

Q38. Do you feel that your vagina is too tight?
0 Never
1 Occasionally
2 Frequently
3 Always

\section{Q41. Do you leak urine during sexual} intercourse?
0 Never
1 Occasionally
2 Frequently
3 Always 